\title{
PERIPHERAL-TYPE BENZODIAZEPINE RECEPTORS IN THE CENTRAL NERVOUS SYSTEM: LOCALIZATION TO OLFACTORY NERVES ${ }^{1}$
}

\author{
RORFRT R. H. ANHOLT, KENNETH M. M. MURPHY, GREGORY E. MACK, AND \\ SOLOMON H. SNYDER ${ }^{2}$
}

Departments of Neuroscience, Pharmacology and Experimental Therapeutics, and Psychiatry and Behavioral Sciences, Johns Hopkins University School of Medicine, Baltimore, Maryland 21205

Received August 25, 1983; Accepted October 4, 1983

\begin{abstract}
Binding levels of $\left[{ }^{3} \mathrm{H}\right]$ Ro5-4864, a ligand selective for peripheral-type benzodiazepine receptors, are substantially higher in homogenates of the olfactory bulb than in the rest of the brain. Among peripheral tissues evaluated, high levels of $\left[{ }^{3} \mathrm{H}\right] \mathrm{Ro5}-4864$ binding are found in the nasal epithelium. Drug displacement studies show that these binding sites are pharmacologically of the peripheral type. Their presence in the nasal epithelium and in the olfactory bulb can be demonstrated in several different mammalian species. Autoradiographic studies of murine nose reveal a bipolar staining pattern around the cell bodies of the olfactory receptor cells, suggesting the presence of peripheral-type benzodiazepine receptors on both processes of these bipolar neurons. In the brain a high density of $\left[{ }^{3} \mathrm{H}\right] \mathrm{Ro5}-4864$ binding sites occurs in the nerve fiber and glomerular layers of the olfactory bulb. Throughout the rest of the brain $\left[{ }^{3} \mathrm{H}\right] \mathrm{Ro} 5-4864$-associated silver grains are diffusely distributed with intense staining over the choroid plexus and along the ependymal linings of the ventricles. Both the distribution and the ontogenic development of the peripheral-type benzodiazepine receptors differ from the central-type receptors. Intranasal irrigation with $5 \% \mathrm{ZnSO}_{4}$ results in a $50 \%$ reduction of peripheral-type benzodiazepine receptors in the olfactory bulb without affecting the density of central-type benzodiazepine receptors. Thus, $\left[{ }^{3} \mathrm{H}\right] \mathrm{Ro} 5-4864$ binding sites in the olfactory bulb appear in large part to be localized to olfactory nerves which originate in the nasal epithelium.
\end{abstract}

Benzodiazepines are a class of anxiolytic and anticonvulsant drugs which interact with specific binding sites in the brain and which are thought to mediate their physiological effects by potentiating the binding of the inhibitory neurotransmitter GABA to its receptor (Braestrup and Squires, 1977; Möhler and Okada, 1977; Tallman et al., 1978, 1980; Wastek et al., 1978; Olson, 1981). A good correlation exists between the anxiolytic potencies of various benzodiazepines and their relative affinities for the benzodiazepine receptor sites in the brain (reviewed by Tallman et al., 1980). In addition, benzodiazepine binding sites have been identified in the

\footnotetext{
${ }^{1}$ This work was supported by a grant of the International Flavors and Fragrances Corporation. We thank Dr. Craig Warren for valuable discussions, Lynda Hester and Naomi Taylor for excellent technical assistance, and Dawn C. Dodson for the preparation of the manuscript.

${ }^{2}$ To whom correspondence should be addressed, at Department of Neuroscience, Johns Hopkins University School of Medicine, 725 North Wolfe Street, Baltimore, MD 21205.
}

kidney and other peripheral tissues (Braestrup and Squires, 1977; Regan et al., 1981). These "peripheral" benzodiazepine binding sites differ significantly from the "central" benzodiazepine receptors in their pharmacological properties. Benzodiazepines which are potent anxiolytics and which bind with high affinity to the central receptors, such as clonazepam, have negligible potency for the peripheral benzodiazepine binding sites (Braestrup and Squires, 1977; Möhler and Okada, 1977; Tallman et al., 1980; Schoemaker et al., 1981, 1982a, 1983; Marangos et al., 1982). Furthermore, in contrast to the central receptors, the binding of benzodiazepines to peripheral receptors is not affected by GABA or chloride ions (Marangos et al., 1982; Schoemaker et al., 1982).

The benzodiazepine Ro5-4864, which is not anxiolytic, has high affinity for the peripheral receptor sites but negligible affinity for the central benzodiazepine binding site (Braestrup and Squires, 1977). [ $\left.{ }^{3} \mathrm{H}\right] \mathrm{Ro5}-4864$ can be used to label peripheral-type benzodiazepine receptor sites in the brain as well as in peripheral tissues (Schoe- 
maker et al., 1981, 1982a, 1983; Marangos et al., 1982). A preliminary autoradiographic study revealed a high density of $\left[{ }^{3} \mathrm{H}\right] \mathrm{Ro5}-4864$ binding sites in the olfactory bulb and a diffuse binding throughout the rest of the brain (Richards et al., 1982). Schoemaker et al. (1982b) demonstrated a significant increase in the number of $\left[{ }^{3} \mathrm{H}\right] \mathrm{Ro5}-4864$ binding sites in the putamen of patients with Huntington's disease and in brains of rats following intrastriatal injections with kainic acid. Since the increase in $\left[{ }^{3} \mathrm{H}\right] \mathrm{Ro5}-4864$ binding sites paralleled a process of glial proliferation, these authors proposed that $\left[{ }^{3} \mathrm{H}\right]$ Ro5-4864 binding sites in the brain may be localized to glia.

In the present study we provide evidence that $\left[{ }^{3} \mathrm{H}\right]$ Ro5-4864 binding observed in the olfactory bulb is localized to olfactory nerves which originate in the nose and terminate in the glomerular layer of the olfactory bulb. Furthermore, we present data from binding experiments and autoradiographic studies which demonstrate a high density of peripheral-type benzodiazepine receptors on the processes of olfactory receptor cells in the nasal epithelium.

\section{Materials and Methods}

Preparation of membranes. Male (150 to $200 \mathrm{gm})$ Sprague-Dawley rats or male (30 to $35 \mathrm{gm}$ ) ICR mice were obtained from Harlan Sprague-Dawley (Walkersville, MD) and Blue Spruce Farms (Altamont, NY), respectively. The animals were sacrificed by cervical dislocation and decapitation, and the brains (without the olfactory bulbs), olfactory bulbs, and peripheral organs were homogenized in ice-cold $50 \mathrm{~mm}$ Tris buffer, $\mathrm{pH} 7.7$, with a Brinkmann Polytron PT-10 at medium speed for 15 sec. Nasal epithelium was obtained while still attached to the septum and turbinate cartilages. The bone and cartilage were crushed with a razor blade, and the nasal epithelium was detached mechanically by vigorous vortexing for $1 \mathrm{~min}$ in $50 \mathrm{~mm}$ Tris buffer, $\mathrm{pH} \mathrm{7.7}$. The cartilage and bone were allowed to settle, and the suspension was carefully decanted. The bones were once again subjected to mechanical agitation in buffer for 1 $\mathrm{min}$, and the resulting suspension was combined with the first one. The pooled tissue suspension was homogenized with a Polytron at medium speed for $15 \mathrm{sec}$. All homogenates were centrifuged at $50,000 \times g$ for $10 \mathrm{~min}$, and the pellets were washed twice by homogenization with the Polytron in $50 \mathrm{~mm}$ Tris buffer, $\mathrm{pH} 7.7$. Final pellets were suspended in $50 \mathrm{~mm}$ Tris buffer, $\mathrm{pH} \mathrm{7.7, \text {and }}$ assayed for protein content using the assay of Lowry et al. (1951) with bovine serum albumin as standard. Prior to use, suspensions of nasal membranes were sometimes filtered through four layers of sterile gauze to remove remaining fragments of cartilage.

Receptor binding assays. $\left[{ }^{3} \mathrm{H}\right]$ Ro5 $-4864(73.8 \mathrm{Ci} / \mathrm{mmol})$, $\left[{ }^{3} \mathrm{H}\right]$ methylclonazepam $(70.0 \mathrm{Ci} / \mathrm{mmol})$, and $\left[{ }^{3} \mathrm{H}\right]$ flunitrazepam $(86.1 \mathrm{Ci} / \mathrm{mmol})$ were obtained from New England Nuclear (Boston, MA). Unlabeled benzodiazepines were a gift from Dr. William Scott (Hoffman-La Roche, Nutley, NJ). Binding assays were performed in triplicate. Each assay contained $0.1 \mathrm{ml}$ of radioactive ligand, $0.1 \mathrm{ml}$ of displacing ligand, and $1.8 \mathrm{ml}$ of membrane suspension containing 0.1 to $0.4 \mathrm{mg}$ of protein in $50 \mathrm{~mm}$ Tris buffer, $\mathrm{pH}$ 7.7. The tubes were incubated in an ice water bath for $1 \mathrm{hr}$. The assays were terminated by vacuum filtration on Whatman GF/B filters followed by one wash with 10 $\mathrm{ml}$ of ice-cold buffer. The filters were extracted in Formula 947 scintillation cocktail (New England Nuclear), and radioactivity was measured in a scintillation counter at $47 \%$ efficiency. Nonspecific binding was defined as binding of $\left[{ }^{3} \mathrm{H}\right]$ Ro5-4864 or $\left[{ }^{3} \mathrm{H}\right]$ methylclonazepam in the presence of $10 \mu \mathrm{M}$ flunitrazepam. Specific binding was calculated by subtracting the nonspecific binding from the total binding. The total binding was routinely at least 3- to 5-fold higher than the nonspecific binding for $\left[{ }^{3} \mathrm{H}\right] \mathrm{Ro5}-4864$ and 6- to 8-fold higher than the nonspecific binding for $\left[{ }^{3} \mathrm{H}\right]$ methylclonazepam.

Autoradiography. For autoradiography, animals were perfused intracardially with $0.1 \%$ paraformaldehyde in phosphate-buffered saline. The brains or noses were removed, embedded in brain paste on a cryostat pedestal, and frozen under powdered dry ice. Cryostat sections (8 $\mu \mathrm{m})$ were incubated with $1 \mathrm{nM}\left[{ }^{3} \mathrm{H}\right] \mathrm{Ro} 5-4864,\left[{ }^{3} \mathrm{H}\right]$ methylclonazepam, or $\left[{ }^{3} \mathrm{H}\right]$ flunitrazepam in $50 \mathrm{mM}$ Tris buffer, $\mathrm{pH} 7.7$, for $40 \mathrm{~min}$ at $0^{\circ} \mathrm{C}$. The sections were washed twice for $5 \mathrm{~min}$ in ice-cold $50 \mathrm{~mm}$ Tris buffer, pH 7.7, and dried under a stream of cold dry air. Autoradiographic exposure was for 12 days using either LKB $\left[{ }^{3} \mathrm{H}\right]$-sensitive Ultrofilm or coverslips coated with Kodak nuclear track emulsion type NTB3. The film or coverslips were developed by standard photographic procedures, and coverslip-covered sections were poststained with toluidine blue or cresyl violet to allow microscopic observation under brightfield and darkfield illumination.

Intranasal irrigation with $\mathrm{ZnSO}_{4}$ and assessment of anosmia. Unanesthetized mice were held on their backs and droplets of a $5 \% \mathrm{ZnSO}_{4}$ solution were slowly deposited one by one from a Hamilton syringe on top of both nostrils. A total volume of 80 to $100 \mu \mathrm{l}$ of $\mathrm{ZnSO}_{4}$ solution was administered to each mouse.

$\mathrm{ZnSO}_{4}$-treated and age-matched control mice were tested for anosmia essentially as described by Harding et al. (1978). The mice were subjected to overnight food deprivation and tested for their ability to locate a buried food pellet. Each mouse was individually placed in a plastic box $(28 \times 17 \times 12 \mathrm{~cm})$ containing a layer (approximately $1 \mathrm{~cm}$ ) of clean bedding (Beta-Chip, Hardwood Laboratory Bedding, Northeastern Products Corp. Warrensburg, NY). The box contained a single pellet of mouse chow $(2 \times 1 \times 0.5 \mathrm{~cm}$; Charles River Laboratories, Wilmington, MA) buried just below the bedding in the center of the cage. Mice were allowed $5 \mathrm{~min}$ to locate the food pellet. The test ended when the mouse held the pellet in its front paws. Ninety-two percent $(n=67)$ of untreated control mice were able to locate the food pellet within the allocated time, and $100 \%$ of these mice were successful when tested a second time. For the second trial the food pellet was moved to a location $7 \mathrm{~cm}$ forward of the center of the cage to prevent the possibility of food localization by learned behavior rather than through smell. Only mice which had demonstrated the ability to localize the food pellet twice were used for $\mathrm{ZnSO}_{4}$ lesions. Mice which failed to localize the food pellet after two trials were considered anosmic. Usually these mice would 
eat immediately when food was presented to them after the test.

\section{Results}

\section{Identification of peripheral-type benzodiazepine receptors in nasal epithelium}

Binding studies. Among various rat tissues examined, the highest levels of $\left[{ }^{3} \mathrm{H}\right] \mathrm{Ro5}-4864$ binding are detected in the nasal epithelium $\left(B_{\max }=4\right.$ to $5 \mathrm{nmol} / \mathrm{gm}$ of protein), the testis, and the kidney, with somewhat lower receptor densities in the lung (Table I). The lowest density of peripheral-type benzodiazepine receptors is found in the brain (without the olfactory bulbs), with $\left[{ }^{3} \mathrm{H}\right]$ Ro5-4864 binding levels only about one-fortieth of the nasal epithelium. Binding in the olfactory bulb is approximately 7 times higher than in the rest of the brain.

Properties of $\left[{ }^{3} \mathrm{H}\right] \mathrm{Ro5}-4864$ binding sites are similar in the various tissues. The dissociation constant is essentially the same in the brain, olfactory bulb, nasal epithelium, and kidney, about 1 to $2 \mathrm{nM}$ (Fig. 1). In addition, several benzodiazepines and related agents compete for the binding sites in brain, kidney, olfactory bulb, and nasal epithelium, with similar potencies and a pharmacological pattern characteristic of peripheral-type receptors (Fig. 2). Of the drugs examined, only diazepam and flunitrazepam as well as Ro5-4864 are effective displacers. The potent anxiolytic clonazepam and the potent benzodiazepine antagonist $\left[{ }^{3} \mathrm{H}\right] \mathrm{Ro} 15-1788$ (Hunkeler et al., 1981) are ineffective at the peripheral-type benzodiazepine binding site (Fig. 2). GABA (0.1 mM) lowers the $K_{D}$ of $\left[{ }^{3} \mathrm{H}\right]$ methylclonazepam for binding to brain membranes by $30 \%$, but it has no effect on the binding of $\left[{ }^{3} \mathrm{H}\right] \mathrm{Ro} 5-4864$, in agreement with previous reports (Marangos et al., 1982; Schoemaker et al., 1983; data not shown).

A high density of peripheral-type benzodiazepine receptors in the nasal epithelium is not species specific for

\section{TABLE I}

Levels of peripheral-type benzodiazepine receptors in different organs of the rat

$B_{\max }$ values were obtained for nasal epithelium, kidney, olfactory bulb, and brain by Scatchard analysis (see also Fig. 1). Subsequently, all tissues were assayed in triplicate at $0.5 \mathrm{nM}\left[{ }^{3} \mathrm{H}\right] \mathrm{Ro5}-4864$, and $B_{\max }$ values were calculated using the values obtained from the Scatchard analyses as standards. 'I'he data presented are within $10 \%$ standard error.

\begin{tabular}{|c|c|}
\hline Tissue & Ro5-4864 Binding Sites \\
\hline & fmol/mg of protein \\
\hline Nasal epithelium & 4610 \\
\hline Testis & 4465 \\
\hline Kidney & 4028 \\
\hline Lung & 3579 \\
\hline Heart & 2048 \\
\hline Vas deferens & 1642 \\
\hline Spleen & 1046 \\
\hline Liver & 931 \\
\hline Olfactory bulb & 879 \\
\hline Tongue & 659 \\
\hline Gut & 430 \\
\hline Brain (without olfactory bulb) & 123 \\
\hline
\end{tabular}

the rat. Substantial levels of $\left[{ }^{3} \mathrm{H}\right] \mathrm{Ro5}-4864$ binding sites are readily demonstrable in the nasal epithelium of mouse, rat, guinea pig, cat, and dog (Fig. 3). However, in some species (mouse and guinea pig) numbers of $\left[{ }^{3} \mathrm{H}\right]$ Ro5-4864 binding sites in the kidney are higher than in the nose. The density of $\left[{ }^{3} \mathrm{H}\right] \mathrm{Ro5}-4864$ binding sites in all species except guinea pig is higher in the olfactory bulb than in the rest of the brain. In none of the species examined can we detect binding of $\left[{ }^{3} \mathrm{H}\right]$ methylclonazepam to membranes from nasal tissue.

Autoradiographic localization of $\left[{ }^{3} \mathrm{H}\right]$ Ro5-4864 binding sites to olfactory receptor cells. Murine rather than rat noses were used for autoradiographic localization of $\left[{ }^{3} \mathrm{H}\right]$ Ro5-4864 binding sites in the olfactory epithelium since they can be cut into sections without prior decalcification. Autoradiography of $\left[{ }^{3} \mathrm{H}\right] \mathrm{Ro5}-4864$ binding sites in coronal sections through the nose reveals under darkfield illumination two dense bands of grains on either side of the layer of cell bodies of the olfactory receptor cells (Fig. 4). No grains are evident over the cell bodies of the olfactory receptor cells, the turbinate cartilages and the seplum, and the subepithelial Bowman's glands.

The olfactory receptor cells are bipolar neurons which extend a short process into the mucus layer, which lines the lumen of the nasal cavity, and a long axon which proceeds through the cribriform plate and into the olfactory bulb, the site of the first synaptic relay. The bipolar pattern of grains observed by autoradiography suggests the presence of peripheral-type benzodiazepine receptors on both the short process and the long axon of the olfactory receptor cells but not on the cell bodies. Binding of $\left[{ }^{3} \mathrm{H}\right] \mathrm{Ro} 5-4864$ to the sections can be prevented by incubation in the presence of $10 \mu \mathrm{M}$ flunitrazepam. In addition, no binding to sections of nasal tissue is observed when autoradiography is performed under identical conditions with $\left[{ }^{3} \mathrm{H}\right]$ methylclonazepam instead of $\left[{ }^{3} \mathrm{H}\right] \mathrm{Ro5}-4864$ (data not shown).

\section{Peripheral-type benzodiazepine receptors in the brain}

Autoradiographic localization of $\left[{ }^{3} \mathrm{H}\right] \mathrm{Ro5}-4864$ binding sites in sagittal sections of the brain reveals a diffuse presence of peripheral-type benzodiazepine receptors throughout the brain (Fig. 5A). Particularly high deposits of silver grains are observed along the ependymal linings of the lateral, third, and fourth ventricles and over the choroid plexus. In addition, a well defined band of silver grains is apparent along the rim of the olfactory bulb.

At higher magnification it is evident that the $\left[{ }^{3} \mathrm{H}\right] \mathrm{Ro} 5$ 4864 binding sites in the olfactory bulb are localized in the nerve fiber layer and the adjacent glomerular layer (Fig. 6, $A$ and $B$ ). The glomerular layer represents the termination point of the primary olfactory nerves which synapse here with mitral cells and various interneuronal cell types (for a review, see Shepherd, 1979).

This localization of the peripheral-type benzodiazepine receptors contrasts sharply with the distribution of central-type benzodiazepine receptors in the brain. As reported previously (Young and Kuhar, 1980), high densities of central benzodiazepine receptors occur throughout the cortex, in the molecular layer of the cerebellum, the dentate gyrus and the hippocampus, in the inferior 


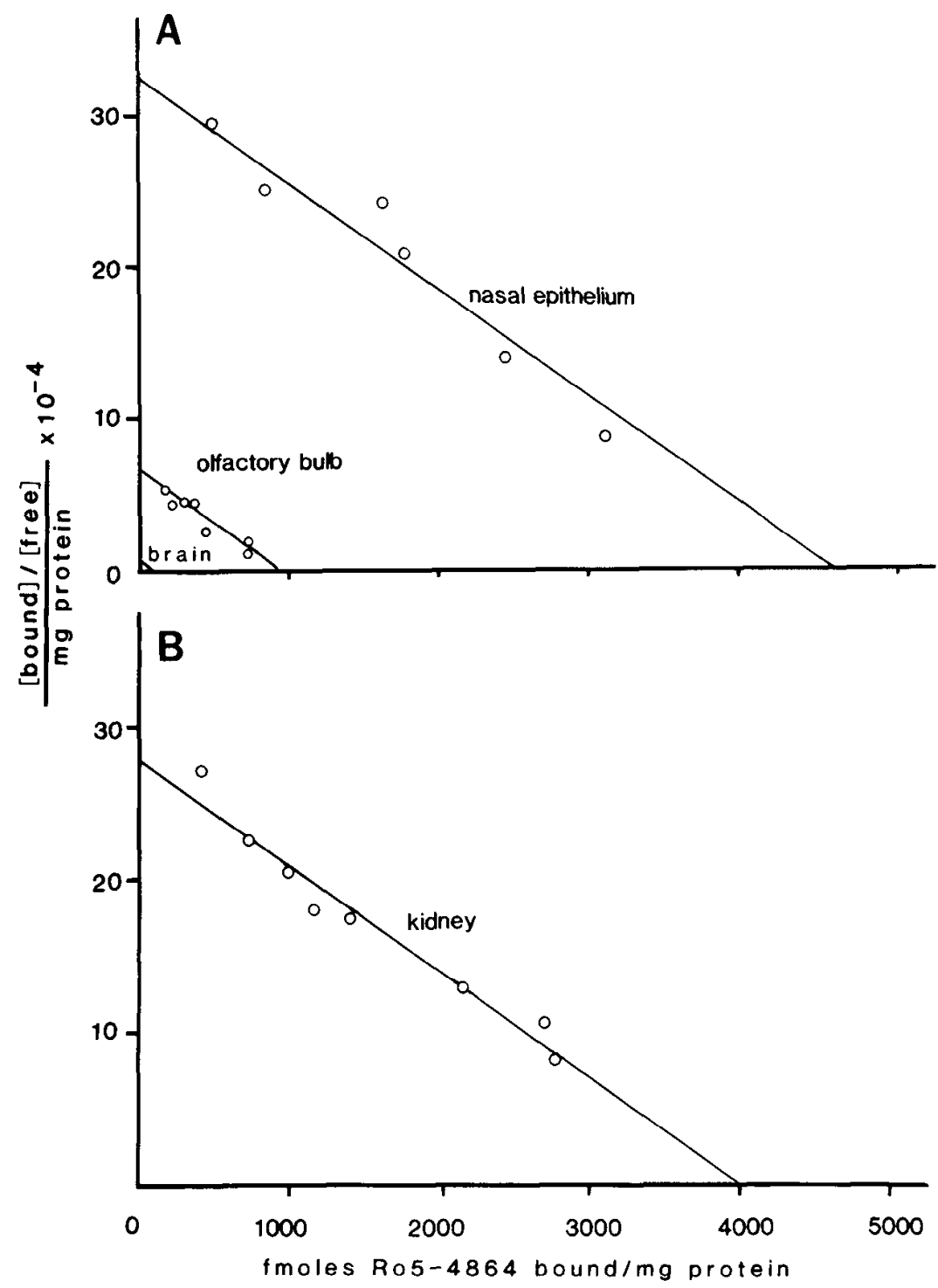

Figure 1. Scatchard plots representing the binding of $\left[{ }^{3} \mathrm{H}\right] \mathrm{Ro5}-4864$ to membranes of various tissues from the rat. Each data point is derived from triplicate measurements of total and nonspecific counts per minute retained on the filters. Each measurement is within $5 \%$ standard error. The best fitted line through the points was calculated by linear regression analysis. Correlation coefficients for the brain (without olfactory bulbs), olfactory bulb, nasal epithelium, and kidney are $0.985,0.924,0.949$, and 0.978 , respectively. The Scatchard plot for the brain is included merely for comparison to illustrate the striking differences in relative concentrations of peripheral-type benzodiazepine receptors in the brain, olfactory bulb, and nasal epithelium. Data points for the brain have been omitted since on this scale they would obscure the line.

and superior colliculi, and as a high-density band in the main olfactory bulb and the accessory olfactory bulb (Fig. 5). However, in contrast to the peripheral-type benzodiazepine receptors, central benzodiazepine receptors appear to be concentrated in the external plexiform layer (Fig. 6, $A$ and $C$ ).

In addition to differences in their localization, peripheral-type and central-type benzodiazepine receptors differ in the time course of their appearance during the ontogeny of the olfactory bulb. $\left[{ }^{3} \mathrm{H}\right] \mathrm{Ro5}-4864$ binding can be detected in the fetal olfactory bulb at near-adult levels at day 19 of gestation, whereas the central-type benzodiazepine receptors appear in the early postnatal period (Fig. 7). In addition, peripheral-type benzodiazepine receptors occur at levels similar to those of adult brain in homogenates of 16-day-old whole embryonic heads, whereas central-type benzodiazepine receptors at this time are undetectable (data not shown). 


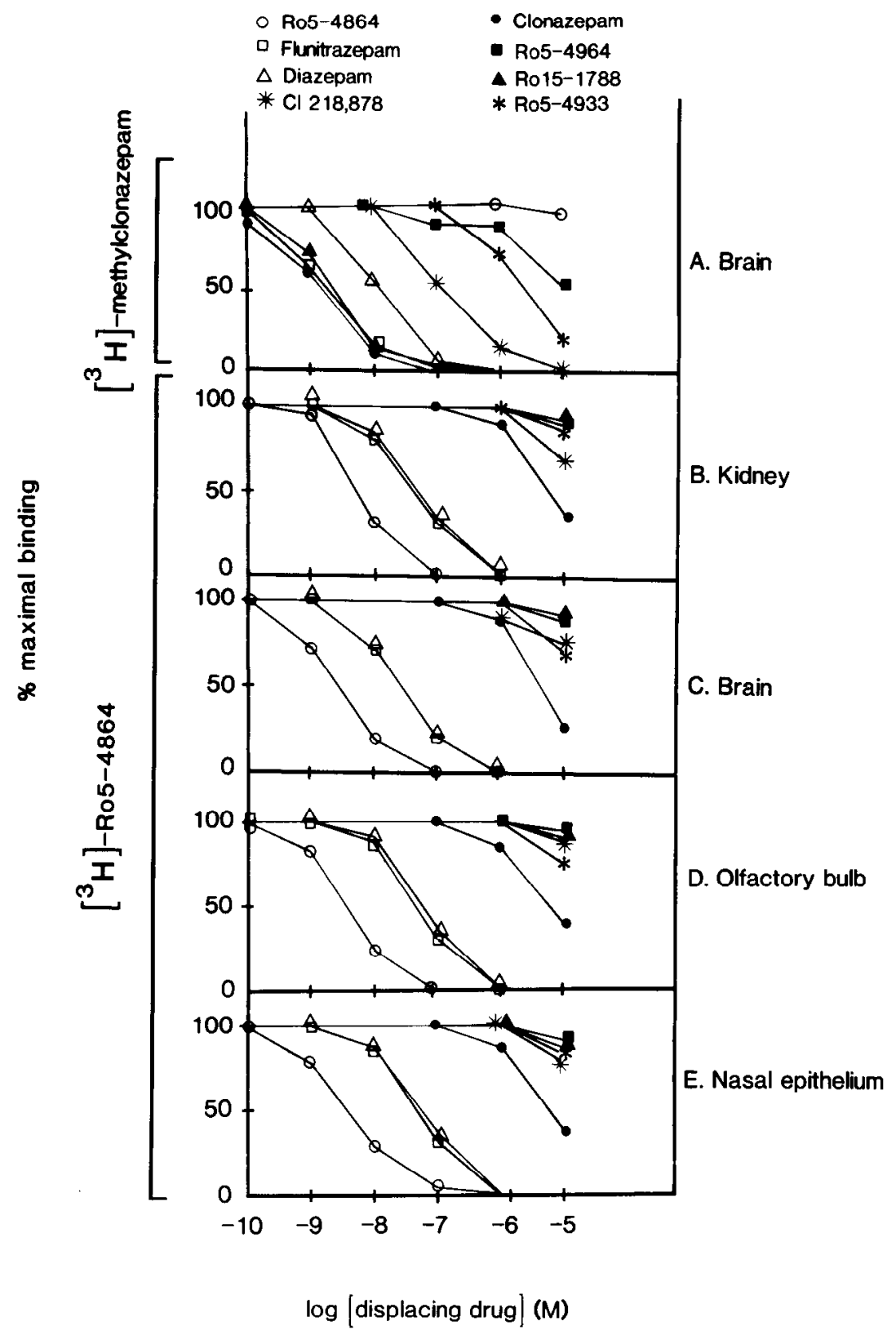

Figure 2. Pharmacological characterization of $\left[{ }^{3} \mathrm{H}\right] \mathrm{Ro5}-4864$ binding sites in different tissues of the rat by competitive displacement with various benzodiazepines. Binding assays were performed with $0.5 \mathrm{nM}$ radioactive ligand in the presence of the indicated concentrations of displacing drug.

Depletion of peripheral-type benzodiazepine receptors in the olfactory bulb after intranasal irrigation with $5 \%$

$$
\mathrm{ZnSO}_{4}
$$

To determine if the binding of $\left[{ }^{3} \mathrm{H}\right] \mathrm{Ro} 5-4864$ in the olfactory bulb arises from primary afferent neurons originating in the olfactory epithelium, we irrigated the nose bilaterally with $5 \% \mathrm{ZnSO}_{4}$. This method has been well documented to cause extensive destruction of the olfactory epithelium in the mouse (Margolis et al., 1974; Matulionis, 1975, 1976; Harding et al., 1978), as well as in several other species (Schultz, 1960; Mulvaney and Heist, 1971; Adameik et al., 1980; Cancalon, 1982), and leads to degeneration of the nerve fiber and glomerular layers within the olfactory bulb (Harding et al., 1978).

We measured the binding of $\left[{ }^{3} \mathrm{H}\right] \mathrm{Ro} 5-4864$ and $\left[{ }^{3} \mathrm{H}\right]$ methylclonazepam in membrane homogenates of the olfactory bulb, the rest of the brain, and the kidney 16 days after a single bilateral irrigation of the nose with $5 \% \mathrm{ZnSO}_{4}$. By this time 6 of 17 lesioned animals had regained their ability to smell as judged by their performance in the food localization test after overnight starvation. Only animals that were anosmic at this time were considered successfully lesioned and used for binding studies. The olfactory bulbs from these animals showed a reduction of $36 \pm 7 \%(n=10)$ in total membrane 


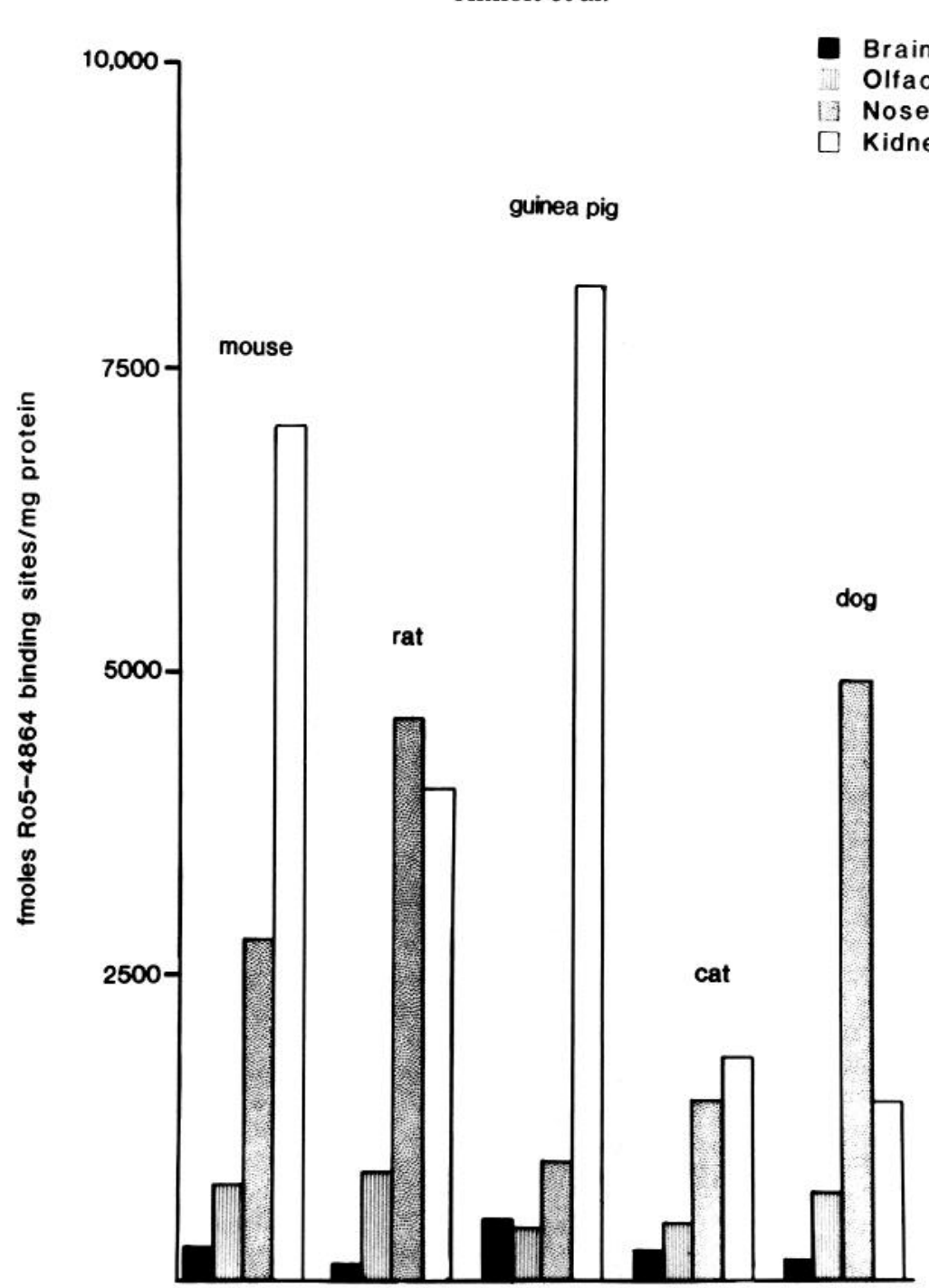

Figure 3. Identification of peripheral-type benzodiazepine receptors in nasal tissue from different mammalian species. Values for maximal binding of $\left[{ }^{3} \mathrm{H}\right] \mathrm{Ro5}-4864$ were measured by extrapolation from Scatchard plots using linear regression analysis, as in Figure 1. The bars are subject to a $10 \%$ standard error. The dissociation constants for $\left[{ }^{3} \mathrm{H}\right] \mathrm{Ro5}-4864$ of the receptors in the nasal epithelium were $2.01 \pm$ $0.20 \mathrm{nM}$ for mouse, $1.27 \pm 0.13 \mathrm{nM}$ for rat, $1.30 \pm 13 \mathrm{nM}$ for guinea pig, $7.8 \pm 2.3 \mathrm{nM}$ for cat, and $6.5 \pm 0.7 \mathrm{nM}$ for dog. Hartley strain guinea pigs were obtained from Buckberg Laboratories (Tomkin Cove, NY) and were sacrificed by decapitation. Cats and dogs were obtained from local physiology laboratories and were sacrificed by lethal injection with pentobarbital. Membranes of tissues from these animals were washed at least six times with 50 vol of $50 \mathrm{~mm}$ Tris buffer, $\mathrm{pH} 7.7$, after homogenization to ensure complete removal of any membrane-bound pentobarbital prior to the binding assay.

protein content as compared to the age-matched controls. The $\mathrm{ZnSO}_{4}$ lesion elicited a $50 \%$ decline of $\left[{ }^{3} \mathrm{H}\right]$ Ro5-4864 binding sites per milligram of protein in the olfactory bulb, whereas $\left[{ }^{3} \mathrm{H}\right] \mathrm{Ro5}-4864$ binding in the brain and kidney was unaffected. It is unlikely that this reduction in $\left[{ }^{3} \mathrm{H}\right] \mathrm{Ro5}-4864$ binding reflects a trans-synaptic effect,since $\left[{ }^{3} \mathrm{H}\right]$ methylclonazepam binding measured in the same homogenates of both olfactory bulb and brain is unaltered, and, as mentioned above, $\left[{ }^{3} \mathrm{H}\right]$ methylclonazepam binding sites are located primarily in the external plexiform layer transsynaptic to the primary olfactory nerve terminals (Table II). Thus, our results suggest that a major portion of the $\left[{ }^{3} \mathrm{H}\right] \mathrm{Ro5}-4864$ binding sites which are present in the olfactory bulb is located on olfactory nerves which are destroyed following the treatment with $\mathrm{ZnSO}_{4}$.

\section{Discussion}

In the present study we have found that peripheraltype benzodiazepine receptors labeled by $\left[{ }^{3} \mathrm{H}\right] \mathrm{Ro5}-4864$ appear to be associated with olfactory neurons in the nose and in the olfactory bulb. This notion is supported 

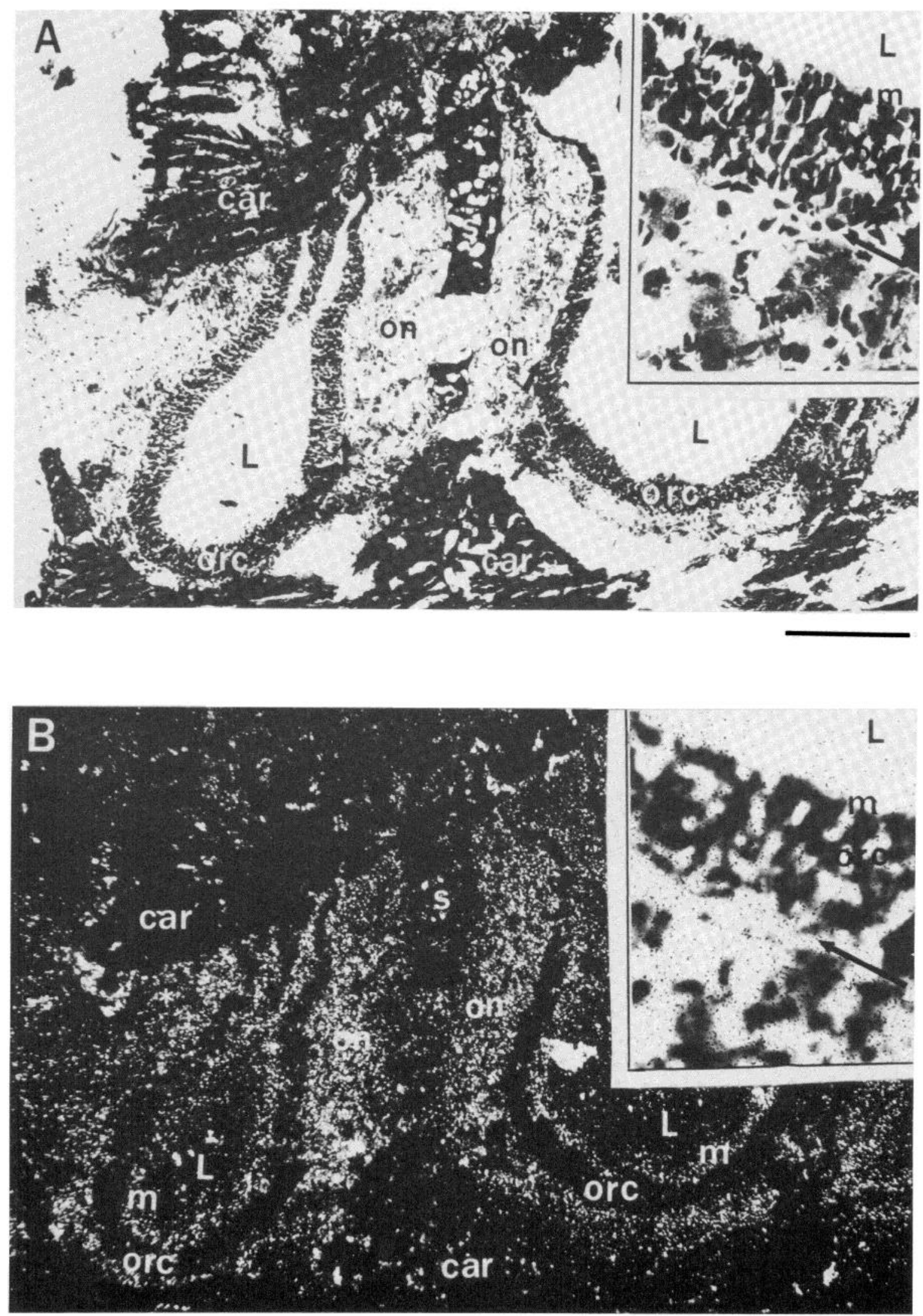

Figure 4. Autoradiographic localization of peripheral-type benzodiazepine receptors in coronal sections through murine nose. Autoradiography was performed with $\left[{ }^{3} \mathrm{H}\right] \mathrm{Ro5}-4864$, and sections were exposed to coverslips coated with Kodak nuclear track emulsion type NTB3. After photographic development they were poststained with toluidine blue and viewed under brightfield $(A)$ and darkfield $(B)$ illumination. The insets show detail at higher magnification with focus on the cells $(A)$ or on the silver grains $(B)$. car, cartilage; $L$, lumen; $m$, mucus layer; on, olfactory nerves; orc, layer of olfactory receptor cell bodies; $s$, septum. The arrows indicate the position of the basement membrane; the asterisks indicate Bowman's glands. The top row of nuclei corresponds to sustentacular cells. Polygonally shaped nuclei on top of the basement membrane represent basal cells. The bar represents $300 \mu \mathrm{m}$. 


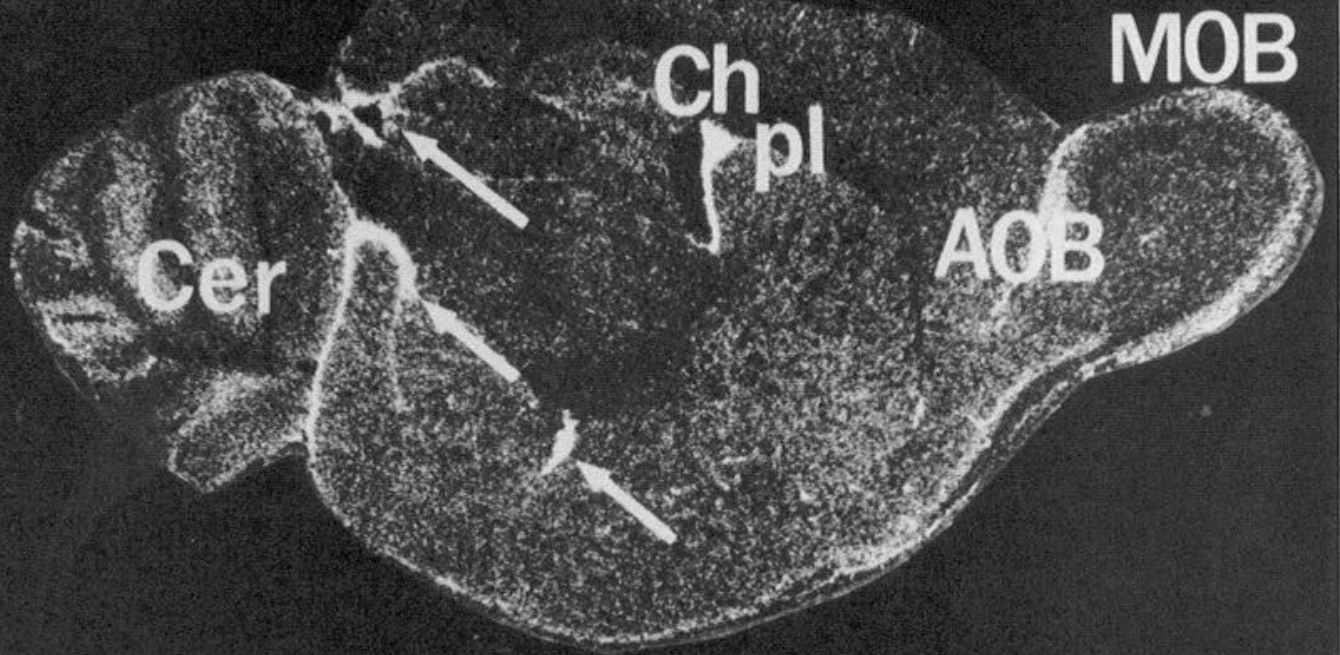

B

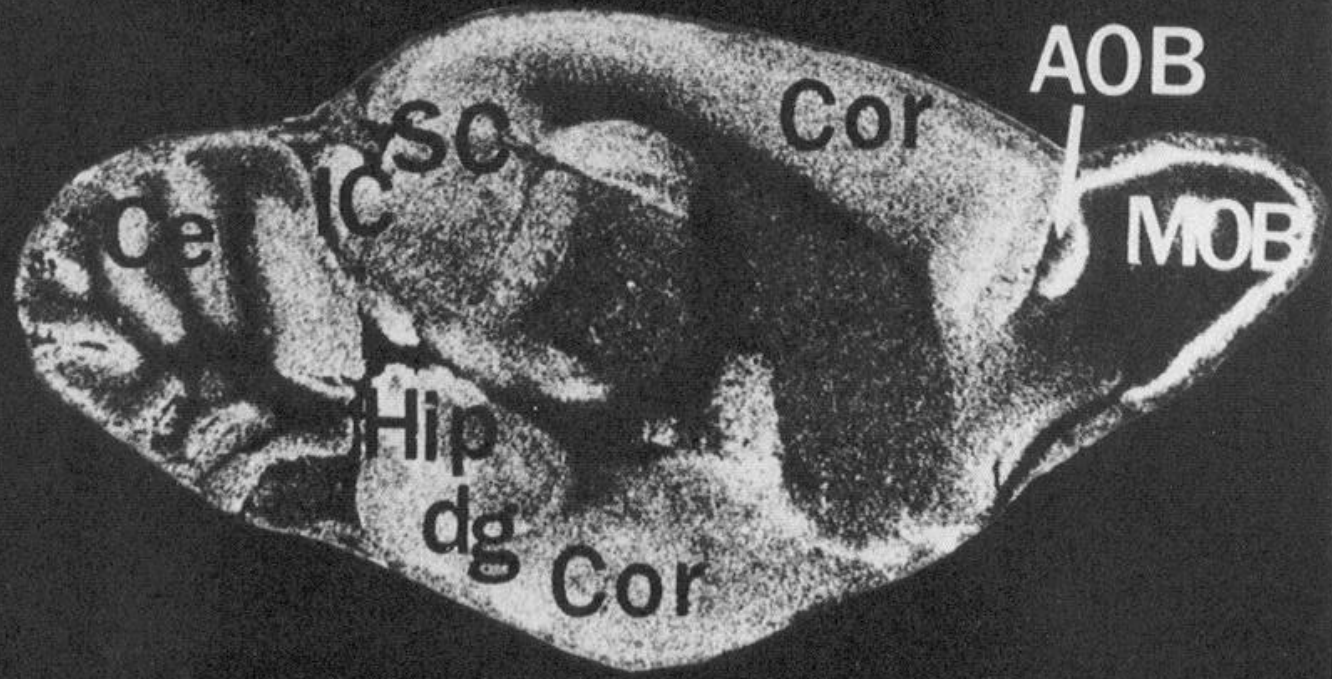

Figure 5. Autoradiographic localization of peripheral-type and central-type benzodiazepine receptors in sagittal sections of murine brain. A, Autoradiography with $\left[{ }^{3} \mathrm{H}\right]$ Ro5-4864. $B$, Autoradiography with $\left[{ }^{3} \mathrm{H}\right]$ methylclonazepam. Autoradiography was performed on $8-\mu \mathrm{m}$-thick cryostat sections as described under "Materials and Methods," and the sections were exposed to LKB ${ }^{3} \mathrm{H}$-sensitive Ultrofilm. $A O B$, accessory olfactory bulb; Cer, cerebellum; $\mathrm{Ch}$ pl, choroid plexus; Cor, cortex; dg, dentate gyrus; Hip, hippocampus; $I C$, inferior colliculus; $M O B$, main olfactory bulb; $S C$, superior colliculus. The arrows in $A$ point at the ependymal linings of the ventricles. 

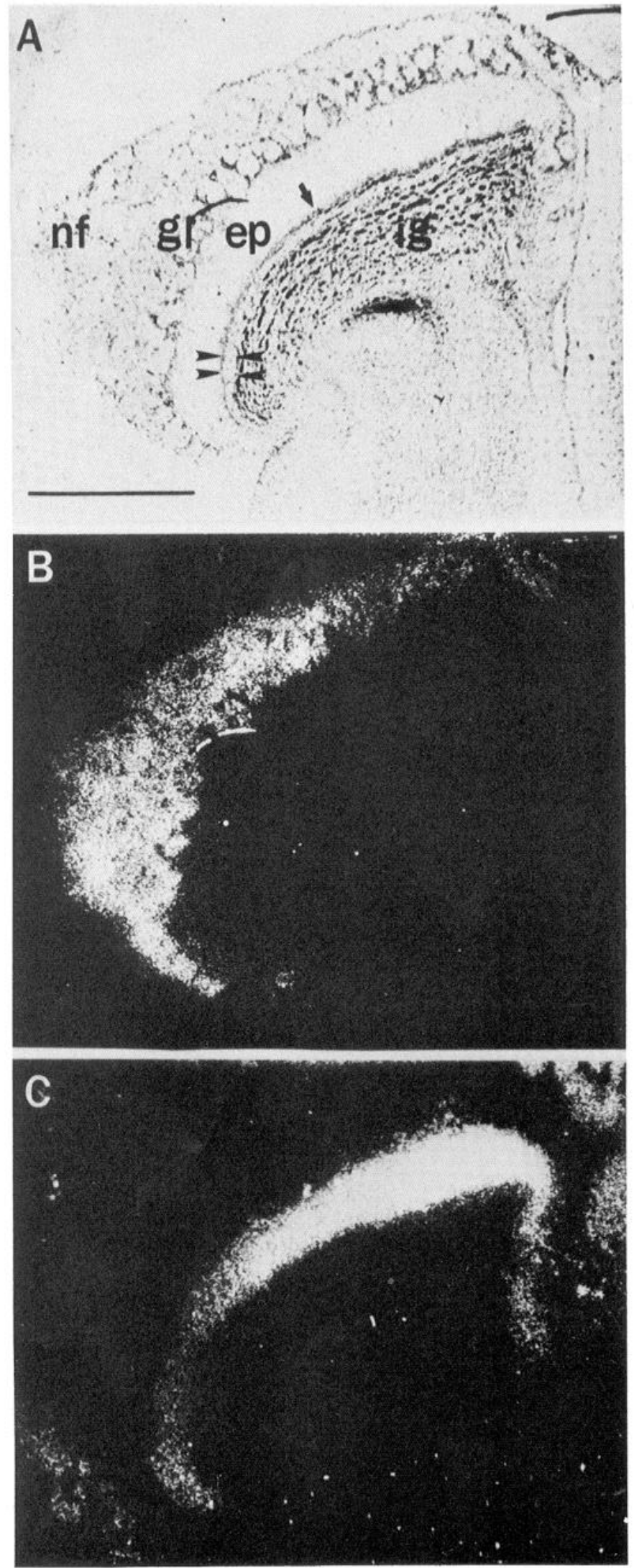

Figure 6. Autoradiographic localization of peripheral-type and central-type benzodiazepine receptors in sagittal sections of rat olfactory bulb. Autoradiography was performed using coverslips coated with Kodak nuclear track emulsion type NTB3, and sections were poststained with cresyl violet. $A$,

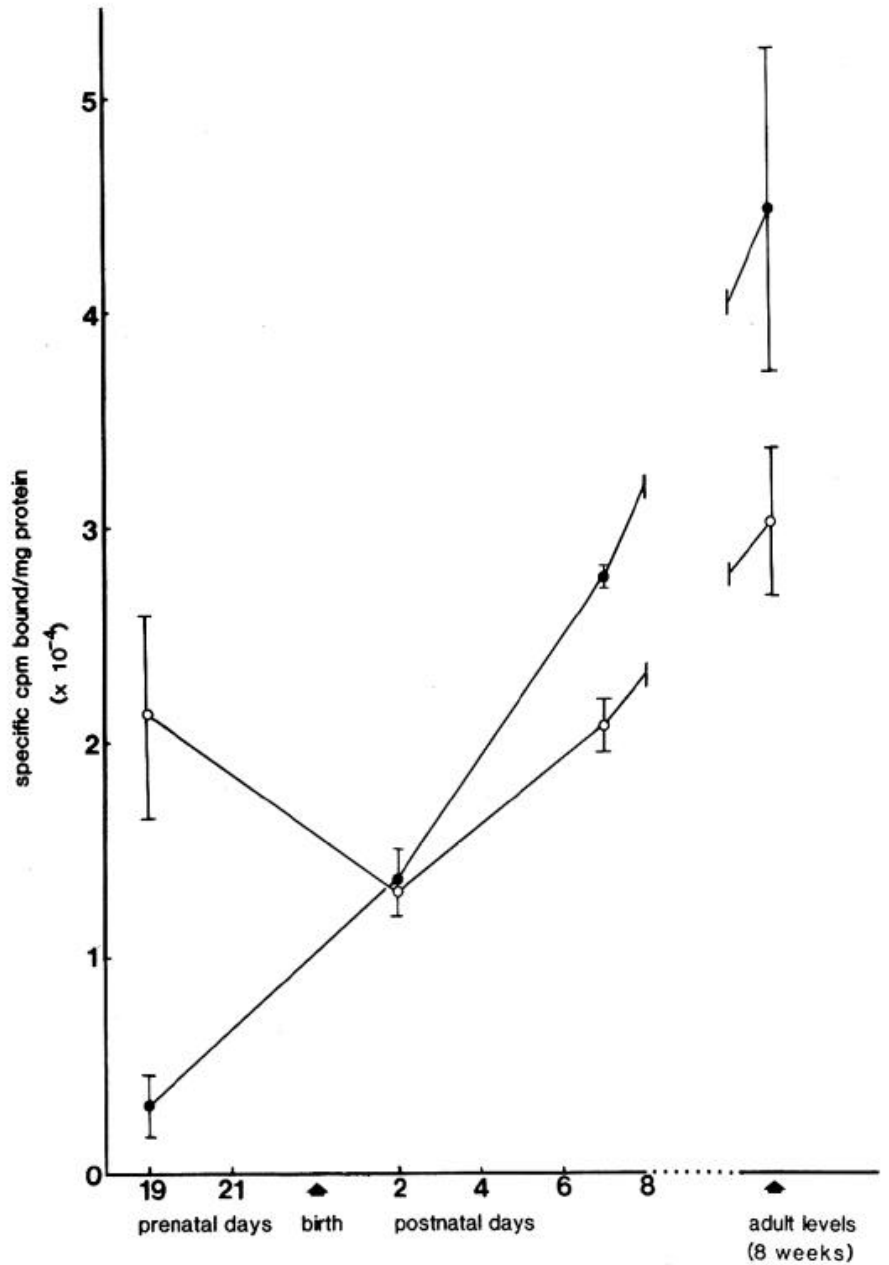

Figure 7. Time course of ontogenic appearance of peripheraltype and central-type benzodiazepine receptors in the rat olfactory bulb. Two-day and 7-day-old neonatal rats were sacrificed by decapitation. Nineteen-day-old prenatal rats were sacrificed by decapitation after removal from the uterus. Membrane preparations of the olfactory bulbs were prepared and assayed for binding of $\left[{ }^{3} \mathrm{H}\right] \mathrm{Ro} 5-4864(\mathrm{O}-\mathrm{O})$ and $\left[{ }^{3} \mathrm{H}\right]$ methylclonazepam (-) at $0.48 \mathrm{nM}$ and $0.57 \mathrm{nM}$, respectively. Data points represent the averages of triplicate assays of five animals.

by several lines of evidence. (1) Binding studies reveal a high density of peripheral-type benzodiazepine receptors in membrane homogenates of nasal epithelium and in the olfactory bulb relative to the rest of the brain. (2) In coronal sections through the nose $\left[{ }^{3} \mathrm{H}\right] \mathrm{Ro} 5-4864$-associated silver grains appear as two bands on either side of the layer of cell bodies of the olfactory receptor cells, suggesting the presence of peripheral-type benzodiazepine receptors on both processes of these bipolar neurons. (3) In the olfactory bulb silver grains are concentrated in the glomerular layer where the primary olfactory

Brightfield autoradiography with $\left[{ }^{3} \mathrm{H}\right] \mathrm{Ro5}-4864$. B, Darkfield, autoradiography with $\left[{ }^{3} \mathrm{H}\right] \mathrm{Ro5}-4864$. $C$, Darkfield, autoradiography with $\left[{ }^{3} \mathrm{H}\right]$ flunitrazepam. $n f$, nerve fiber layer; $g l$, glomerular layer; $e p$, external plexiform layer; ig, internal granule layer. The arrow indicates the mitral cell body layer; the internal plexiform layer is indicated by the arrowheads. The bar represents $300 \mu \mathrm{m}$. 
TABLE II

Effect of bilateral intranasal irrigation with $5 \% \mathrm{ZnSo}_{4}$ on the density of peripheral-type benzodiazepine receptors in the olfactory bulbs of the mouse

Data are the averages of two independent experiments, each of which consisted of triplicale measurements of five individual mice. $\left[{ }^{3} \mathrm{H}\right] \mathrm{Ro5}$ 4864 was present at a concentration of $0.66 \mathrm{nM}$, and $\left[{ }^{3} \mathrm{H}\right]$ methylclonazepam was used at $0.91 \mathrm{nM}$. All of the $10 \mathrm{ZnSO}_{4}$-lesioned mice represented in this table were anosmic as judged from their inability to locate food after overnight starvation.

\begin{tabular}{|c|c|c|c|c|c|}
\hline \multirow[b]{2}{*}{ Treatment } & \multicolumn{3}{|c|}{ Binding of $\left[{ }^{3} \mathrm{H}\right] \mathrm{Ro5}-4864$} & \multicolumn{2}{|c|}{ Binding of $\left[{ }^{3} \mathrm{H}\right]$ Methylclonazepam } \\
\hline & $\begin{array}{l}\text { Olfactory } \\
\text { Bulb }\end{array}$ & Brain & Kidney & $\begin{array}{l}\text { Olfactory } \\
\text { Bulb }\end{array}$ & Brain \\
\hline & \multicolumn{3}{|c|}{$\underset{\left(\times 10^{-4}\right)}{c p m / m g} \underset{\text { protein }}{ } \pm S E M$} & \multicolumn{2}{|c|}{$\underset{\left(\times 10^{-4}\right)}{c p m / m g \text { protein }} \pm S E M$} \\
\hline Control & $2.26 \pm 0.49$ & $1.19 \pm 0.16$ & $12.04 \pm 0.94$ & $5.36 \pm 0.32$ & $3.43 \pm 0.21$ \\
\hline $\begin{array}{l}\text { Treated with } 5 \% \\
\mathrm{ZnSO}_{4}\end{array}$ & $1.13 \pm 0.15^{a}$ & $1.19 \pm 0.10$ & $12.28 \pm 1.74$ & $4.92 \pm 0.29$ & $3.38 \pm 0.30$ \\
\hline
\end{tabular}

${ }^{a} p<0.1$ versus control.

afferent axons terminate, and in the olfactory nerve layer which is apposed to the glomerular layer. (4) Destruction of the olfactory epithelium by intranasal irrigation with $\mathrm{ZnSO}_{4}$ depletes $\left[{ }^{3} \mathrm{H}\right] \mathrm{Ro5}-4864$ binding sites in the olfactory bulb, in agreement with observations by Hirsch and Margolis (1981), who reported a decrease of $\left[{ }^{3} \mathrm{H}\right]$ diazepam binding in the olfactory bulb after peripheral deafferentation with $\mathrm{ZnSO}_{4}$.

The possibility that some of the $\left[{ }^{3} \mathrm{H}\right] \mathrm{Ro5}-4864$ binding sites in the olfactory bulb reside on glial structures, as in the rest of the brain (Schoemaker et al., 1982b), may account for the observation that intranasal irrigation with $\mathrm{ZnSO}_{4}$ does not fully abolish $\left[{ }^{3} \mathrm{H}\right] \mathrm{Ro} 5-4864$ binding in the olfactory bulb. It is also possible that the $\mathrm{ZnSO}_{4}$ lesions were incomplete or that at the 16-day time point examined in this study some regeneration of the olfactory epithelium had taken place (Matulionis, 1976), although the mice which were used for measurements of $\left[{ }^{3} \mathrm{H}\right]$ Ro54864 binding appeared anosmic.

Central-type as well as peripheral-type benzodiazepine receptors occur with high density in the olfactory bulb. However, the central-type receptors occur in the external plexiform layer, whereas the peripheral-type binding sites are concentrated in the olfactory nerve layer and the glomerular layer. The central-type receptors in the olfactory bulb are not affected by $\mathrm{ZnSO}_{4}$ lesions and are not detectable in the nasal epithelium of any species examined either by direct binding of $\left[{ }^{3} \mathrm{H}\right]$ methylclonazepam to membrane homogenates or by autoradiography. Thus, central-type benzodiazepine receptors are not associated with primary olfactory neurons.

Peripheral-type benzodiazepine receptors can be detected in the fetal olfactory bulb at least 4 days before birth. By this time the main afferent olfactory pathway which involves the synaptic relay between olfactory neurons from the nasal epithelium and mitral cells in the olfactory bulb is intact (Gesteland et al., 1982). The localization of $\left[{ }^{3} \mathrm{H}\right] \mathrm{Ro5}-4864$ binding sites in the nerve fiber and glomerular layers of the olfactory bulb and their prenatal presence in the olfactory bulb are consistent with their localization on the axons of olfactory receptor cells, which terminate in the glomerular layer and which are well developed by day 16 of gestation (Gesteland et al., 1982; Bayer, 1983). The complex interneuronal circuitry which modulates the relay of primary olfactory information originates largely in the first post- natal weeks (Mair et al., 1982; Bayer, 1983). The localization of central-type benzodiazepine receptors in the external plexiform layer of the olfactory bulb together with their postnatal development suggests that these receptors may be present on interneurons.

The function of the peripheral-type benzodiazepine receptor is still unknown. Recently, Ro5-4864 at dosages of $\sim 30 \mathrm{mg} / \mathrm{kg}$ has been reported to have some anxiogenic activity and to elicit seizures in mice and rats (File and Lister, 1983). This rather weak anxiogenic activity does not appear to correlate well with the high affinity of Ro5-4864 for the peripheral-type benzodiazepine binding site. Moreover, $\left[{ }^{3} \mathrm{H}\right]$ Ro5-4864-induced seizures do not shed light on what the role might be of peripheral-type benzodiazepine receptors on olfactory nerves and in peripheral tissues.

Several hypotheses can be considered regarding the role of peripheral-type benzodiazepine receptors on olfactory nerves. It is conceivable that peripheral-type benzodiazepine receptors may modulate odorant recognition, the firing rate of the olfactory neurons, or neurotransmitter release. Alternatively, peripheral-type benzodiazepine receptors may play a role in the growth and differentiation of the olfactory receptor cells. The olfactory epithelium has a unique regenerative capacity, and olfactory receptor cells are known to turn over rapidly throughout the life span of the animal. The halflife time of olfactory neurons in the mouse is 4 to 6 weeks (Moulton, 1974). New receptor cells are continuously generated from neurogenic stem cells in the base of the olfactory epithelium (Moulton et al., 1970; Moulton, 1974; Matulionis, 1975, and 1976; Harding et al.,1977; Cancalon, 1982). Perhaps peripheral-type benzodiazepine receptors play a role in directing axonal growth and cell differentiation of the olfactory neurons. The observation that Ro5-4864, acting through a peripheral-type benzodiazepine receptor site, promotes the growth of melanoma cells in culture and enhances the onset of melanin synthesis (Matthew et al., 1981) lends some support to this hypothesis.

\section{References}

Adameik, G. P., R. G. Mair, and R. C. Gesteland (1980) Transduction processes in regenerating olfactory epithelium. Soc. Neurosci. Abstr. 6: 243.

Bayer, S. A. (1983) $\left[{ }^{3} \mathrm{H}\right]$ Thymidine-radiographic studies of 
neurogenesis in the rat olfactory bulb. Exp. Brain Res. 50: $329-340$.

Braestrup, C., and R. F. Squires (1977) Specific benzodiazepine receptors in rat brain characterized by high-affinity $\left[{ }^{3} \mathrm{H}\right]$ diazepam binding. Proc. Natl. Acad Sci. U. S. A. 74: 38053809.

Cancalon, P. (1982) Degeneration and regeneration of olfactory cells induced by $\mathrm{ZnSO}_{4}$ and other chemicals. Tissue Cell 14: 17-733.

File, S. E., and R. G. Lister (1983) The anxiogenic action of $\left[{ }^{3} \mathrm{H}\right]$ Ro5-4864 is reversed by phenytoin. Neurosci. Lett. 35: 93-96.

Gesteland, R. C., R. A. Yancey, and A. I. Farbman (1982) Development of olfactory receptor neuron selectivity in the rat fetus. Neuroscience 7: 3127-3136.

Harding, J., P. P. C. Graziadei, G. A. Monti-Graziadei, and F. L. Margolis (1977) Denervation in the primary olfactory pathway of mice. IV. Biochemical and morphological evidence for neuronal replacement following nerve section. Brain Res. 132: 11-28.

Harding, J. W., T. V. Getchell, and F. L. Margolis (1978) Denervation of the primary olfactory pathway in mice. $\mathrm{V}$. Long-term effect of intranasal $\mathrm{ZnSO}_{4}$ irrigation on behavior, biochemistry and morphology. Brain Res. 140: 271-285.

Hirsch, Y. O., and F. L. Margolis (1981) Isolation, separation and analysis of cells from olfactory epithelium. In Biochemistry of Taste and Olfaction, R. H. Cagan and M. R. Kare, eds., pp. 331-332, Academic Press, Inc., New York.

Hunkeler, W., H. Möhler, L. Pieri, P. Polc, E. P. Bonetti, R. Cumin, R. Schaffner, and W. Haefely (1981) Selective antagonists of benzodiazepines. Nature 290: 514-516.

Lowry, O. H., N. J. Rosebrough, A. L. Farr, and R. J. Randall (1951) Protein measurement with the Folin phenol reagent. J. Biol. Chem. 193: 265-275

Mair, R. G., R. L. Gellman, and R. C. Gesteland (1982) Postnatal proliferation and maturation of olfactory bulb neurons in the rat. Neuroscience $7: 3105-3116$.

Marangos, P. J., J. Patel, J. -P. Boulenger, and R. ClarkRosenberg (1982) Characterization of peripheral-type benzodiazepine binding sites in brain using $\left[{ }^{3} \mathrm{H}\right] \mathrm{Ro} 5-4864$. Mol. Pharmacol. 22: 26-32.

Margolis, F. L., N. Roberts, D. Ferriero, and J. Feldman (1974) Denervation in the primary olfactory pathway of mice: Biochemical and morphological effects. Brain Res. 81: 469-483.

Matthew, E., J. D. Laskin, E. A. Zimmerman, I. B. Weinstein, K. C. Hsu, and D. L. Engelhardt (1981) Benzodiazepines have high-affinity binding sites and induce melanogenesis in GB16/C3 melanoma cells. Proc. Natl. Acad. Sci. U. S. A. 78: 3935-3939.

Matulionis, D. H. (1975) Ultrastructural study of mouse epithelium following destruction by $\mathrm{ZnSO}_{4}$ and its subsequent regeneration. Am. J. Anat. 142: 67-90.

Matulionis, D. H. (1976) Light and electron microscopic study of the degeneration and early regeneration of olfactory epithelium in the mouse. Am. J. Anat. 145: 79-100.
Möhler, H., and T. C. Okada (1977) Benzodiazepine receptor: Demonstration in the central nervous system. Science 198: 849-851.

Moulton, D. G. (1974) Dynamics of cell populations in the olfactory epithelium. Ann. N. Y. Acad. Sci. 237: 52-61.

Moulton, D. G., G. Celebi, and R. P. Fink (1970) Olfaction in mammals - two aspects: Proliferation of cells in the olfactory epithelium and sensitivity to odours. In Taste and Smell in Vertebrates, G. E. W. Wolstenholme and J. Knight, eds., pp. 227-246, Churchill Press, London.

Mulvaney, B. D., and H. E. Heist (1971) Regeneration of rabbit olfactory epithelium. Am. J. Anat. 131: 241-252.

Olson, R. W. (1981) GABA-benzodiazepine-barbiturate receptor interactions. J. Neurochem. 31: 1-13.

Regan, J. W., H. I. Yamamura, S. Yamada, and W. R. Roeske (1981) High affinity renal $\left[{ }^{3} \mathrm{H}\right]$ flunitrazepam binding: Characterization, localization and alterations in hypertension. Life Sci. 28: 991-998.

Richards, J. C., H. Möhler, and W. Haefely (1982) Benzodiazepine binding sites: Receptors or acceptors? Trends Pharmacol. Sci. 3: 233-235.

Schoemaker, H., M. Bliss, and H. I. Yamamura (1981) Specific high-affinity saturable binding of $\left[{ }^{3} \mathrm{H}\right] \mathrm{Ro5}-4864$ to benzodiazepine binding sites in the rat cerebral cortex. Eur. J. Pharmacol. 71: 173-175.

Schoemaker, H., M. Bliss, S. H. Yamamura, D. Horst, and H. I. Yamamura (1982a) Demonstration of $\left[{ }^{3} \mathrm{H}\right] \mathrm{Ro5}-4864$ binding to benzodiazepine sites in brain and kidney. In Brain Peptides and Hormones, R. Collu et al., eds., pp. 115-123, Raven Press, New York.

Schoemaker, H., M. Morelli, P. Deshmukh, and H. I. Yamamura (1982b) $\left[{ }^{3} \mathrm{H}\right] \mathrm{Ro5}-4864$ benzodiazepine binding in the kainate lesioned striatum and Huntington's diseased basal ganglia. Brain Res. 248: 396-401.

Schoemaker, H., R. G. Boles, W. D. Horst, and H. I. Yamamura (1983) Specific high-affinity binding sites for $\left[{ }^{3} \mathrm{H}\right] \mathrm{Ro5}-4864$ in rat brain and kidney. J. Pharmacol. Exp. Ther. 225: 6169.

Schultz, E. W. (1960) Repair of the olfactory mucosa. Am. J. Pathol. 37: 1-19.

Shepherd, G. M. (1979) Olfactory bulb. In The Synaptic Organization of the Brain, pp. 152-183, Oxford University Press, New York.

Tallman, J. F., Y. J. Thomas, and D. W. Gallagher (1978) GABAergic modulation of benzodiazepine binding site sensitivity. Nature 274: 383-385.

Tallman, J. F., S. M. Paul, P. Skolnick, and D. W. Gallager (1980) Receptors for the age of anxiety: Pharmacology of the benzodiazepines. Science 207: 274-281.

Wastek, G. J., R. C. Speth, T. D. Reisine, and H. I. Yamamura (1978) The effect of GABA on $\left[{ }^{3} \mathrm{H}\right]$ flunitrazepam binding in rat brain. Eur. J. Pharmacol. 50: 445-447.

Young, W. S. III, and M. J. Kuhar (1980) Radiohistochemical localization of benzodiazepine receptors in rat brain. J. Pharmacol. Exp. Ther. 212: 337-346. 